\title{
Study the Impact of Quality Control on Production Processes
}

\author{
Dr. Ameen $\mathrm{Zahra}^{1}$
}

\begin{abstract}
Authors affiliations:
1) Textile Engineering Department, Faculty of Chemical and Petroleum Engineering, Al-baath University, Syria. ameen.zahra6@gmail.com
\end{abstract}

\section{Paper History:}

Received: $8^{\text {th }}$ Aug. 2019

Revised: $15^{\text {th }}$ Sep. 2019

Accepted: $29^{\text {th }}$ Jan. 2020

\begin{abstract}
The research aims to improve the quality of the product through improving the quality of production processes by relying on the principle of quality control, the aim of this research is to identify the reality of quality control in the industrial public sector companies in Syria, and explaining the advantages of using the principle of quality control producing information and data that contribute to improve the quality of production, where the research was based on theoretical side to provide an explanation on the quality and its objectives and the principle of quality control and production processes, but on the practical side, the workers were surveyed at the General Company for Wool and Carpets in Hama.
\end{abstract}

To achieve the objective of the research and to prove or deny the impact of quality control on the quality of production processes was based on the descriptive analytical method and using the appropriate statistical methods, where statistical analysis was carried out using SPSS 19 program.

The statistical results have shown that there is a strong correlation between the quality control and improving the quality of production processes.

The researcher recommended the need to form an administrative structure or forming a team work to improve the quality or using the consultants and researchers in order to supervise on the principle of quality control.

Keywords: Quality, SPSS, The Statistical Analysis, Quality Control, The Production Processes.

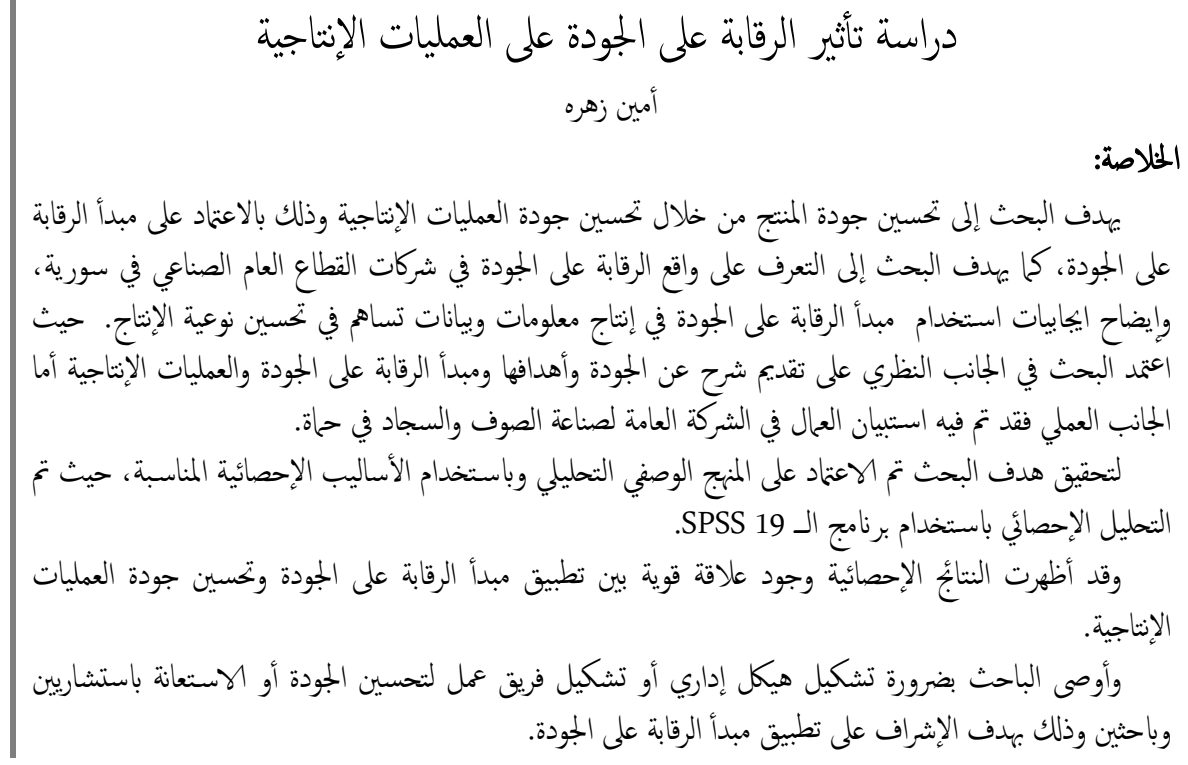

direct and direct impact on the performance of the organization [2].

The search for quality of work was not the result of a certain time or period of time but rather a continuous activity and fundamental to the performance of individuals and groups. The search for quality has evolved in line with evolving

NJES is an open access Journal with ISSN 2521-9154 and eISSN 2521-9162

This work is licensed under a Creative Commons Attribution-NonCommercial 4.0 International License 
circumstances and changing needs [3]. Quality has become an important competitive weapon that no modern company or institution can face the challenges posed by globalization without being armed it. Quality is one of the most important principles of management at present, and it is understood that if the company's products can compete in the field of quality, these products become competitive in the international markets also, and the most important definitions of quality:

- The American Quality Association defines it as: a set of advantages and characteristics of a product or service capable of meeting the needs of consumers [4].

- ISO defines it: the set of characteristics of an entity (activity, process, product, service, organization, system, person, or combination thereof) that make it meet or able to meet the stated and expected needs [5].

\section{2- Research Objective:}

The aim of this research is to identify the reality of quality control in the industrial public sector companies in Syria, by studying the reality of the general company for wool and carpets in Hama as a sample.

- Knowing the impact of control on the quality of production processes and thus the quality of products.

- Explaining the advantages of using the principle of quality control producing information and data that contribute to improve the quality of production.

\section{3-Research Importance:}

This research is a scientific contribution to light the importance of quality control, which improves the quality and competitiveness of products, which enhances the role of the public sector in Syria because it suffers from a weakness in the quality level, and we point in this regard to the responsibility of companies in producing products that meet the needs of consumers in terms of specifications and price.

\section{4- Research Method:}

To achieve the objective of the research and to prove or deny the impact of quality control on the quality of production processes was based on the descriptive analytical method and using the appropriate statistical methods, where Statistical analysis was carried out using SPSS 19 program.

\section{5- Quality Importance:}

Quality is of great strategic importance both at the level of consumers and at the level of institutions for their different activities and at the national level of the country, as it represents the most important and fundamental factors that determine the demand for the company's products or services and a source of competitive advantage [6]. So, achieving quality is a dream for all organizations, and quality is important to three main parties: organization, customers, and the work [7].

\section{6- Quality Objectives:}

Quality is a goal that every organization seeks to achieve in order to reach customer satisfaction; these objectives include [8]:

1- Providing products and services that conform to the design and achieve the needs of the customer and their superiority.

2- Prohibiting the provision of products and services that cause customer dissatisfaction.

3- Detecting and reducing undesirable manifestations of goods and services.

4- Increasing the ratio of outputs to inputs, this means increasing productivity.

5- High efficiency of operations and reduce the cost of the adjustment and cost of internal and external failure.

6- Improving the efficiency of resources and the productive process leads the company to improve the competitive position.

7- Increasing market share leads to increased returns.

8- Maintaining of an advanced position for the production of competing companies.

9- Eliminating the causes of increased damage and defects in products.

10- The use of technical techniques in the work to reduce the damage and redo.

\section{8- Quality Control: Control concept:}

Control is an administrative function that aims to ensure that the objectives are achieved according to plan, by following up their implementation and comparing the actual results with the expected results, so that the administration can use the results of this this comparison to develop future plans [9]. It is also known as: it is the competent administrative function to ensure the proper functioning of the work and its harmony with the plans established to achieve them and to detect and address possible errors before they occur [10]. Also, it is defined as: a management function that monitors performance and adjusts organizational activities in line with achieving the objectives [11].

\section{Quality Control concept:}

Control means verifying that performance is as planned, in order to achieve the desired objectives. As quality is one of the most important of these objectives in modern industrial companies, quality control is the means to achieve this goal. Quality control means: controlling the products to reach the specified level of quality in accordance with the specifications specified by the company concerned [12]. Kaplan defined it as a set of functions and actions undertaken by the organization to enforce achieving specific objectives [13].

And it can also be defined: it is a set of predetermined steps that aims to ensure that the production achieved conforms to the basic specifications and characteristics of the product [14]. 
The researcher believes that quality control is a set of predefined steps that aim to ensure that the production is in conformity with the basic specifications and characteristics of the product.

\section{Quality Control Objectives:}

The quality control process aims to [15]:

1- Reducing the percentage of sales returns resulted from low quality.

2- Maintaining the degree of conformity of the final product with the original design specifications that have been developed for this product.

3- Reducing the size of defect in the purchased materials in order not to affect the quality of finished products.

4- Reducing the number of customers complaints of quality.

5- Reducing the cost of quality control and inspection of the productive units.

6- Reducing the proportion of materials that are re-operated due to low quality.

\section{9- Production Processes:}

\section{Production Processes Concept:}

Production Processes are the implementation and re- implementation of the various designs of the products according to the arranged processes and according to the same specifications each time [16].

The quality of the production and operations is the quality associated with the actual production conditions through conform the produced goods to the specifications set. This depends on the suitability of the specifications set within the quality of the design with the technological capabilities that are available to the company and the performance of the workers during the production process. And the more the product's specifications are fully consistent with the technological capabilities of the production process, the higher the quality of production.

\section{Production Processes Definition:}

The process of production is the mean by which a product or service is produced, A process is a particular combination of machines, personnel, working methods, resources, tools and environmental factors that all convert inputs into outputs of goods or services. The concept of the process is not limited to change the physical form as in the manufacture of the product, it extends to change ownership by selling the product, change the site by moving the product from one place to another or change its existing condition when the product is maintained or repaired [17].

\section{0- Field study:}

Study variables:

1- Independent variable: quality control X.

2- Dependent variable: is the production process measured by the quality of products $\mathrm{Y}$.

$\mathrm{Y}=\mathrm{F}(\mathrm{X})$

\section{Study Hypothesis:}

There is one main hypothesis for the study:
There is no statistically significant impact of the quality control in the company on machinery the production processes.

\section{Community and Sample Research:}

The study community consists of all workers in the general company for the manufacture of wool and carpet in Hama, and the sample of the research is a comprehensive sample of the employees in the company mentioned. The questionnaire was distributed to (110) workers from all the units selected to represent the community in question.

After the forms were retrieved, they were sorted and entered into the computer, and the research was adopted on SPSS 19 for the statistical analysis.

\section{Building Research Tool:}

Design of the form based on studies and research on the subject of quality control.

The form consists of three sections arranged as follows:

1- The first section includes the questions related to the demographic characteristics of the members of the research sample represented by: (gender, age, certification, current work, experience, salary).

2- Section II: consists of phrases related to the independent variable the quality control, the number of phrases (5) phrases.

3- Section III: consists of phrases related to the dependent variable (the production processes), and the number of phrases (11) phrases.

Each of its terms corresponds to a list of five options according to the five-caliber Likert scale [18] arranged as follows: (strongly agree, agree, neutral, disagree, strongly disagree). For statistical processing, the above options were given certain grades: strongly agree (5 degrees), agree (4 grades), neutral (3 grades), disagree (2 grades), strongly disagree (1 grade), and the questionnaire is valid for measuring the measurements prepared by:

\section{A - The apparent honesty:}

The questionnaire was presented to a number of arbitrators to determine its accuracy in measuring what was set up for it. The number of arbitrators for the questionnaire was 2 arbitrators from the Faculty of Economics at the University of Hama. In the light of the arbitrators' opinions, some of the phrases were modified, deleted, reworded, and other terms added. The form was finalized as follows:

\section{Part 1: Personal Data:}

2- Age: less than 30 $30-40 \square$ More than $40 \square$

3- Certification: less than bachelor' degree $\square$ bachelor' degree $\square$ institute' degree $\square$

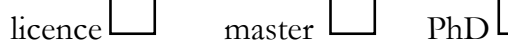

4- Current work: administrative work worker

5- Experience: 1-5 $\square$ 6-10 $\square$ More than 10 6- Salary: less than 30 thousand $\square$

30-40 thousand $\square$ more than 40 thousand $\square$ 


\section{Part II: Data on Variables:}

Please answer the following questions by making a correct mark to what you see fit:

\begin{tabular}{|c|c|c|c|c|c|c|}
\hline & The questions & $\mathrm{Th}$ & 1e & ans & swe & \\
\hline & & 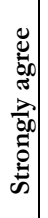 & \} $&{\text { 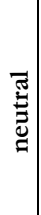 }} &{\text { 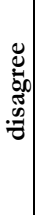 }} &{\text { 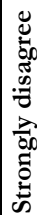 }} \\
{\hline} &{\text { 1- The Quality Contro }} &{ } &{ } &{ } &{ } &{ } \\
{\hline \text { C1 }} &{\begin{array}{l}\text { The company measures the quality in all } \\
\text { areas of the work. }\end{array}} &{ } &{ } &{ } &{ } &{ } \\
{\hline C 2} &{\begin{array}{l}\text { The company uses charts and graphs } \\
\text { during measuring the quality. }\end{array}} &{ } &{ } &{ } &{ } &{ } \\
{\hline \text { C3 }} &{\begin{array}{l}\text { The company uses statistical methods } \\
\text { during measuring the quality. }\end{array}} &{ } &{ } &{ } &{ } &{ } \\
{\hline C 4} &{\begin{array}{l}\text { Training the workers on quality } \\
\text { measurement methods (statistics, charts } \\
\text { and graphs). }\end{array}} &{ } &{ } &{ } &{ } &{ } \\
{\hline \text { C5 }} &{\begin{array}{l}\text { The company measures the quality of the } \\
\text { finished product only. }\end{array}} &{ } &{ } &{ } &{ } &{ } \\
$\hline
\end{tabular}

\section{2- The Production Processes}

\begin{tabular}{|c|l|l|l|l|l|l|}
\hline P1 & $\begin{array}{l}\text { The company has an officially announced } \\
\text { goal of producing flawless products }\end{array}$ & & & & \\
\hline P2 & $\begin{array}{l}\text { The company has a program for } \\
\text { continuous reduction of defects }\end{array}$ & & & & & \\
\hline P3 & $\begin{array}{l}\text { There is a plan to reduce the same } \\
\text { processes due to defects }\end{array}$ & & & & & \\
\hline P4 & $\begin{array}{l}\text { The company follows a flexible } \\
\text { manufacturing system }\end{array}$ & $\begin{array}{l}\text { The company implements storage systems } \\
\text { at perfect time }\end{array}$ & & & & \\
\hline P6 & $\begin{array}{l}\text { The company benefits from the } \\
\text { experience of others in manufacturing }\end{array}$ & & & & \\
\hline P7 & $\begin{array}{l}\text { In the company, the operations are } \\
\text { controlled statistically }\end{array}$ & & & & \\
\hline P8 & $\begin{array}{l}\text { In the company, there is a program to } \\
\text { reduce the time cycle of the processes }\end{array}$ & & & & \\
\hline P9 & $\begin{array}{l}\text { In the company, there is a program to } \\
\text { reduce the time of development cycle of } \\
\text { the product }\end{array}$ & & & & & \\
\hline P10 & $\begin{array}{l}\text { In the company, there is a program to } \\
\text { reduce the delivery time of the product }\end{array}$ & & & & \\
\hline P11 & $\begin{array}{l}\text { There is a program to determine the lost } \\
\text { time in the company }\end{array}$ & & & \\
\hline
\end{tabular}

Note: Before the workers answered questions in the

questionnaire, the working instructions for the international standard were explained.

C: symbol indicates to the axis of quality control.

- P: symbol indicates the axis of production processes.

\section{B- Stability of the measuring instrument (Reliability):}

The consistency test was performed on the research sample using the Alpha Cronbach coefficient. The measurement tool is consistently meant to be the internal consistency between its terms, and the internal consistency of the questionnaire questions means the strong correlation between the degrees for each field and the overall questionnaire degree. The stability of the tool has two aspects. The first is the stability of the scale, such as obtaining the same results if the variable is measured in consecutive times, as for the other side of the stability, it is objective, that is the same degree is obtained regardless of the person applying the test or who designed it. The Alpha Cronbach correlation coefficient is between 0-1 and until the measure is stable, the minimum value of the coefficient must not be less than (0.70) [19]. Table (1) shows the results of the Alpha Cronbach analysis for each section of the form.

Table (1) Alpha Cronbach coefficient of the research

\begin{tabular}{|c|c|c|}
\hline \multicolumn{3}{|c|}{ axes } \\
\hline THE AXIS & $\begin{array}{c}\text { ALPHA } \\
\text { CRONBACH }\end{array}$ & $\begin{array}{l}\text { STABILITY } \\
\text { ASSESSMENT }\end{array}$ \\
\hline \multicolumn{3}{|c|}{ The first section: the quality control } \\
\hline $\begin{array}{l}\text { The quality } \\
\text { control }\end{array}$ & 0.719 & Normal \\
\hline \multicolumn{3}{|c|}{ The second section: the production processes } \\
\hline $\begin{array}{l}\text { the production } \\
\text { processes }\end{array}$ & 0.816 & High \\
\hline
\end{tabular}

The table was prepared based on the results of the statistical analysis of the questionnaire.

Note from Table (1) that the value of the Alpha Cronbach coefficient is greater than (0.70), indicating that the search tool is internally consistent between its phrases.

Where the value of the Alpha Cronbach parameter should not be less than 0.7 , and if the coefficient value is between 0.7 and 0.8 , the internal consistency between the terms is normal, but if the parameter value is between 0.8 and 0.9 , the internal consistency of the terms is high, the parameter value is more than 0.9 The consistency between the terms is very high.

\section{-Validity the search tool:}

Researchers divide the validity of the scale into several types [20]:

* Content Validation (Face Validity):

It aims to ensure the compatibility of the phrases contained in the measuring tool with the subject being studied, which is based on the judgment and personal assessment by researchers.

*Theoretical Validity:

The extent of reliance on the preparation of the measuring instrument in the study is based on previous theories and research and the accepted principles in the same field.

*Convergent Validity:

It determines the degree of coherence of concepts and phrases that measure the same thing with the total score of the scale. The higher the degree of correlation in the scale of all the variables or phrases to be measured, the more the measurement tool achieves the objective for which it is designed.

Based on the nature of the research, we have used the Exploratory Factor Analysis method, which aims to examine the data, for looking for a structure that expresses a set of variables and is a tool for reducing the data by using the Principle Component method and the maximum variation method (Varimax) that is vertical for the rotation of the correlation matrix axes [21], and the convergent validity of the used scale in the results of the analysis can be judged as follows:

1- The standard of variance rate: "the total explained variance for all factors", there is no minimum rate, yet researchers agree in the field of 
social sciences such as the economy that $60 \%$ or more acceptable [22].

2- Eigen values: The Eigen value of the factor must be at least 1 before it can be said to be statistically significant, and the Eigen value can be defined as: sum of the total variance extracted by the factor [23].

3- Saturation of factors: To know when the saturation of the factors is significant and statistically significant based on the size of the sample can be seen in Table (2) [24], which shows that, where the size of the sample in this research is equal to (110) form, saturation can be considered significant and statistically significant if the absolute value of that saturation is greater or equal to 0.55 .

Table (2) mean saturation according to sample size

\begin{tabular}{|c|c|}
\hline $\begin{array}{c}\text { The appropriate sample } \\
\text { size (greater or equal) }\end{array}$ & $\begin{array}{c}\text { Factor saturation (absolute } \\
\text { values) }\end{array}$ \\
\hline 350 & 0.30 \\
\hline 250 & 0.35 \\
\hline 200 & 0.40 \\
\hline 150 & 0.45 \\
\hline 120 & 0.50 \\
\hline 100 & 0.55 \\
\hline
\end{tabular}

-Statistical analysis:

I. Descriptive Statistics:

A. Distribution of the sample according to the gender:

Table (3) distribution of the sample according to the

\begin{tabular}{|l|c|c|c|}
\hline Gender & Frequency & Percent & $\begin{array}{c}\text { Cumulative } \\
\text { percent }\end{array}$ \\
\hline Male & 104 & 94.5 & 94.5 \\
\hline Female & 6 & 5.5 & 100.0 \\
\hline Total & 110 & 100.0 & \\
\hline
\end{tabular}

B. Distribution of the sample according to the age:

Table (4) distribution of the sample according to the age

\begin{tabular}{|c|c|c|c|}
\hline Age & Frequency & Percent & $\begin{array}{c}\text { Cumulative } \\
\text { percent }\end{array}$ \\
\hline Less than 30 & 14 & 12.727 & 12.727 \\
\hline 30 to 40 & 48 & 43.636 & 56.363 \\
\hline More than 40 & 48 & 43.636 & 100.0 \\
\hline Total & 110 & 100.0 & \\
\hline
\end{tabular}

C. Distribution of the sample according to the certification:

Table (5) distribution of the sample according to the certification

\begin{tabular}{|c|c|c|c|}
\hline Certification & Frequency & Percent & $\begin{array}{c}\text { Cumulative } \\
\text { percent }\end{array}$ \\
\hline Less than bachelor & 49 & 44.545 & 44.545 \\
\hline Bachelor' degree & 32 & 29.09 & 73.636 \\
\hline Institute & 16 & 14.545 & 88.181 \\
\hline Licence & 13 & 11.818 & 100.0 \\
\hline Master & 0 & 0 & \\
\hline PhD & 0 & 0 & \\
\hline Total & 40 & 100.0 & \\
\hline
\end{tabular}

D. Distribution of the sample according to the current work:

Table (6) distribution of the sample according to the current work

\begin{tabular}{|c|c|c|c|}
\hline Current work & Frequency & Percent & $\begin{array}{c}\text { Cumulative } \\
\text { percent }\end{array}$ \\
\hline Administrative work & 29 & 26.4 & 26.4 \\
\hline Worker & 81 & 73.6 & 100.0 \\
\hline Total & 110 & 100.0 & \\
\hline
\end{tabular}

E. Distribution of the sample according to the experience:

Table (7) distribution of the sample according to the experience

\begin{tabular}{|c|c|c|c|}
\hline Experience & Frequency & Percent & $\begin{array}{c}\text { Cumulative } \\
\text { percent }\end{array}$ \\
\hline 1 to 5 & 7 & 6.4 & 6.4 \\
\hline 6 to 10 & 25 & 22.7 & 29.1 \\
\hline More than 10 & 78 & 70.9 & 100.0 \\
\hline Total & 110 & 100.0 & \\
\hline
\end{tabular}

F. Distribution of the sample according to the salary:

Table (8) distribution of the sample according to the salary

\begin{tabular}{|c|c|c|c|}
\hline Salary & Frequency & Percent & $\begin{array}{c}\text { Cumulative } \\
\text { percent }\end{array}$ \\
\hline Less than 30 & 9 & 8.2 & 8.2 \\
\hline 30 to 40 & 56 & 50.9 & 59.1 \\
\hline More than 40 & 45 & 40.9 & 100.0 \\
\hline Total & 110 & 100.0 & \\
\hline
\end{tabular}

\section{Results of the factor analysis:}

In order to reach at acceptable results through using the method of factor analysis applied in this research, the standards that are used for all axes related to the original variables of the study must have the Convergent Validity. To achieve this, the following conditions must be met:

1- The conditions for using the main factor analysis are:

A) The absolute value of the parameter of the correlation coefficients matrix is not equal to zero.

B) Pass the Kaiser-Meyer-Olkin (KMO) test to indicate the sufficiency of the sample size well and test whether the partial correlations between the variables are small, the value of this test ranges between zero and one, although the unacceptable limit is less than 0.50 [25].

C) To achieve the significant level of the Bartlett test, this requires that the value of this test be less than (0.05), to indicate the existence of at least some significant correlation between the variables, sufficient to use the factor analysis method. The Bartlett's test is a method used in statistics to evaluate whether variances are similar or equal in the available samples.

2- The saturations of the standard phrases on each of the extracted factors shall be greater than the appropriate acceptance limit (0.55) for the size of a sample between (100) form and (120) form. And all values of the Eigen values before the rotation for all the factors must be greater than one to achieve the criterion of the Eigen values. 
3- The percentage of interpreted variance by the combined factors must be greater than the minimum acceptable in social research $(60 \%)$ [26].

\section{1- Validation the validity of the quality control axis:}

In order to test the validation of the validity of the quality control axis, we must know the terms of this axis, which reflect the original variables, and are included in the following table:

Table (9) terms of the axis of the quality control:

\begin{tabular}{|c|l|}
\hline $\begin{array}{c}\text { THE } \\
\text { SYMBOL }\end{array}$ & $\begin{array}{l}\text { THE PHRASES OF THE SCALE OF THE } \\
\text { FIRST AXES }\end{array}$ \\
\hline C1 & $\begin{array}{l}\text { The company measures the quality in all areas } \\
\text { of the work. }\end{array}$ \\
\hline C2 & $\begin{array}{l}\text { The company uses charts and graphs during } \\
\text { measuring the quality. }\end{array}$ \\
\hline C3 & $\begin{array}{l}\text { The company uses statistical methods during } \\
\text { measuring the quality. }\end{array}$ \\
\hline C4 & $\begin{array}{l}\text { Training the workers on quality measurement } \\
\text { methods (statistics, charts and graphs). }\end{array}$ \\
\hline C5 & $\begin{array}{l}\text { The company measures the quality of the } \\
\text { finished product only. }\end{array}$ \\
\hline \\
$\begin{array}{l}\text { The table was prepared according to the questionnaire prepared } \\
\text { for this research. }\end{array}$
\end{tabular}

The results of the factor analysis of the phrases that are representing the quality control variables, and the saturation of these variables by their representative factors can be included in the following table

Table (10) results of the analytical analysis of the scale of the quality control

\begin{tabular}{|c|c|c|}
\hline \multirow{2}{*}{$\begin{array}{c}\text { THE PHRASES } \\
\text { OF THE } \\
\text { SCALE OF } \\
\text { THE FIRST } \\
\text { AXES }\end{array}$} & \multicolumn{2}{|c|}{$\begin{array}{c}\text { THE SATURATION OF THE } \\
\text { FACTORS }\end{array}$} \\
\hline & $\begin{array}{c}\text { Factor1 } \\
\text { Using statistics } \\
\text { to measure the } \\
\text { quality }\end{array}$ & $\begin{array}{c}\text { Factor2 } \\
\text { Measuring the } \\
\text { quality of the } \\
\text { final product }\end{array}$ \\
\hline C1 & -- & 0.708 \\
\hline C2 & 0.948 & -- \\
\hline C3 & 0.980 & -- \\
\hline C4 & 0.974 & -- \\
\hline C5 & -- & 0.807 \\
\hline $\begin{array}{c}\text { The Eigen value } \\
\text { before the } \\
\text { rotation }\end{array}$ & 2.916 & 1.133 \\
\hline $\begin{array}{l}\text { The Eigen value } \\
\text { after the rotation }\end{array}$ & 2.8767 & 1.182 \\
\hline $\begin{array}{c}\text { The percentage } \\
\text { of the interpreted } \\
\text { variance }\end{array}$ & 57.331 & 23.640 \\
\hline $\begin{array}{c}\text { The percentage } \\
\text { of the total } \\
\text { interpreted }\end{array}$ & 57.331 & 80.971 \\
\hline
\end{tabular}

The table was prepared based on the results of the statistical analysis of the questionnaire.

It is clear from the previous table that two factors were extracted from all the phrases related to the variables of the quality control. These factors were interpreted by $(80.971 \%)$ of the total variance of the terms in this axis, and these two factors are:

- The first factor (Using statistics to measure the quality): This factor was loaded by three phrases, and this factor was interpreted as $(57.331 \%)$ of the total variance of terms.
- The second factor (Measuring the quality of the final product): This factor was loaded by two phrases, and this factor was interpreted as $(23.640 \%)$ of the total variance of terms.

The extracted factors for this axis can be represented according to the Scree Plot test which was created by the scientist Catel 1 as follows:

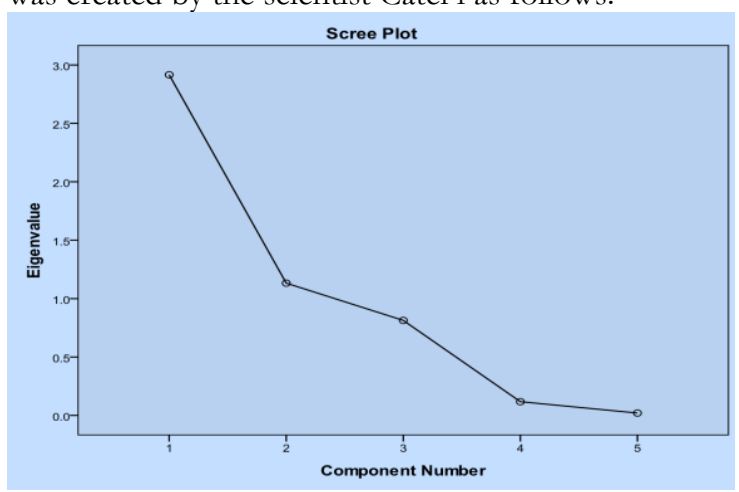

The graph is based on the SPSS output.

Figure (1) graph of Scree Plot Test for the axis of the quality control

From the above we can say that the used scales in this research regarding the axis or section related to the variables of the axis of the quality control all have the credibility of the Convergence Validity for the following reasons:

1- The conditions for using the main factor analysis are achieved:

- The absolute value of the parameter of the correlation coefficients matrix is not equal to zero, the value of the parameter here is Determinant $=$ 0.006 .

- The Kaiser-Meyer-Olkin (KMO) scale is 0.715 and is larger than the desired limit (0.70). This indicates that the size of the sample is well enough. The unacceptable limit is less than 0.50 .

- The Bartlett test is 0.000 , which is less than 0.05 , ( 0.05 is the level of significance in statistical analysis or probability of error, whereas most statistical analyzes are performed at a confidence level of $95 \%$ ), therefore the significant correlation between some variables are enough to use the method of factor analysis, and table (11) shows the results of the KMO and Bartlett test.

Table (11) results of the quality control

\begin{tabular}{|c|c|c|}
\hline KMO TEST & \multicolumn{2}{|c|}{715.0} \\
\hline \multirow{3}{*}{ Bartlett TEST } & Approx. Chi-Square & 537.259 \\
\cline { 2 - 3 } & Degrees of freedom & 10 \\
\cline { 2 - 3 } & significance & 0.000 \\
\hline
\end{tabular}

The table was prepared based on the results of the statistical analysis of the questionnaire.

2- The saturations of the scale phrases on the extracted factors are strong and greater than the appropriate acceptance limit (0.55) for a sample size between (100) form and (120) form. The Eigen values before the rotation for the extracted factors are greater than one and are achieving the Eigen value criterion.

3- The percentage of interpreted variance of the extracted factors is $(80.971 \%)$, which is higher than the accepted minimum in social research $(60 \%)$. 
2- Validation the validity of the scale of the production processes axis:

In order to test the validation of the validity of the production processes axis, we must know the terms of this axis, which reflect the original variables, and are included in the following table:

Table (12) terms of the axis of the production processes

\begin{tabular}{|c|c|}
\hline \begin{tabular}{c|} 
THE \\
SYMBOL
\end{tabular} & $\begin{array}{l}\text { THE PHRASES OF THE SCALE OF THE } \\
\text { SECOND AXES }\end{array}$ \\
\hline P1 & $\begin{array}{l}\text { The company has an officially announced } \\
\text { goal of producing flawless products }\end{array}$ \\
\hline P2 & $\begin{array}{l}\text { The company has a program for continuous } \\
\text { reduction of defects }\end{array}$ \\
\hline P3 & $\begin{array}{l}\text { There is a plan to reduce the same processes } \\
\text { due to defects }\end{array}$ \\
\hline P4 & $\begin{array}{l}\text { The company follows a flexible } \\
\text { manufacturing system }\end{array}$ \\
\hline P5 & $\begin{array}{l}\text { The company implements storage systems at } \\
\text { perfect time }\end{array}$ \\
\hline P6 & $\begin{array}{l}\text { The company benefits from the experience of } \\
\text { others in manufacturing }\end{array}$ \\
\hline P7 & $\begin{array}{l}\text { In the company, the operations are controlled } \\
\text { statistically }\end{array}$ \\
\hline P8 & $\begin{array}{l}\text { In the company, there is a program to reduce } \\
\text { the time cycle of the processes }\end{array}$ \\
\hline P9 & $\begin{array}{l}\text { In the company, there is a program to reduce } \\
\text { the time of development cycle of the product }\end{array}$ \\
\hline P10 & $\begin{array}{l}\text { In the company, there is a program to reduce } \\
\text { the delivery time of the product }\end{array}$ \\
\hline P11 & $\begin{array}{l}\text { There is a program to determine the lost time } \\
\text { in the company }\end{array}$ \\
\hline
\end{tabular}

The table was prepared according to the questionnaire prepared for this research

The results of the factor analysis of the phrases that are representing the production processes variables, and the saturation of these variables by their representative factors can be included in the following table:

Table (13) results of the analytical analysis of the scale of the production processes

\begin{tabular}{|c|c|c|c|}
\hline \multirow[b]{2}{*}{$\begin{array}{c}\text { THE } \\
\text { PHRASES OF } \\
\text { THE SCALE } \\
\text { OF THE } \\
\text { FIRST AXES }\end{array}$} & \multicolumn{3}{|c|}{$\begin{array}{l}\text { THE SATURATION OF THE } \\
\text { FACTORS }\end{array}$} \\
\hline & $\begin{array}{l}\text { Factor1 } \\
\text { available a } \\
\text { program to } \\
\text { reduce the } \\
\text { time cycle of } \\
\text { the product }\end{array}$ & $\begin{array}{c}\text { Factor2 } \\
\text { available a } \\
\text { program } \\
\text { to reduce } \\
\text { the } \\
\text { defects } \\
\end{array}$ & $\begin{array}{c}\text { Factor3 } \\
\text { applying } \\
\text { storage } \\
\text { systems and } \\
\text { control } \\
\text { method } \\
\end{array}$ \\
\hline P1 & -- & 0.723 & -- \\
\hline $\mathbf{P 2}$ & -- & 0.813 & -- \\
\hline P3 & \multicolumn{3}{|c|}{ Delete for non-saturation with any factor } \\
\hline $\mathbf{P 4}$ & -- & 0.657 & -- \\
\hline P5 & -- & -- & 0.808 \\
\hline P6 & \multicolumn{3}{|c|}{ Delete for non-saturation with any factor } \\
\hline P7 & -- & -- & 0.746 \\
\hline P8 & 0.707 & -- & -- \\
\hline P9 & 0.949 & -- & -- \\
\hline P10 & 0.948 & - & -- \\
\hline P11 & \multicolumn{3}{|c|}{ Delete for non-saturation with any factor } \\
\hline $\begin{array}{c}\text { The Eigen value } \\
\text { before the } \\
\text { rotation }\end{array}$ & 3.846 & 1.632 & 1.195 \\
\hline $\begin{array}{c}\text { The Eigen value } \\
\text { after the } \\
\text { rotation }\end{array}$ & 2.573 & 2.091 & 2.010 \\
\hline $\begin{array}{c}\text { The percentage } \\
\text { of the } \\
\text { interpreted } \\
\text { variance }\end{array}$ & 23.390 & 19.005 & 18.270 \\
\hline $\begin{array}{c}\text { The percentage } \\
\text { of the total } \\
\text { interpreted }\end{array}$ & 23.390 & 42.395 & 60.665 \\
\hline
\end{tabular}

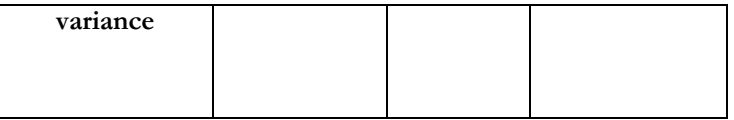

The table was prepared based on the results of the statistical analysis of the questionnaire.

It is clear from the previous table that three factors were extracted from all the phrases related to the variables of the production processes. These factors were interpreted by $(60.665 \%)$ of the total variance of the terms in this axis, and these factors are:

- The first factor (available a program to reduce the time cycle of the product): This factor was loaded by three phrases, and this factor was interpreted as $(23.390 \%)$ of the total variance of terms.

- The second factor (available a program to reduce the defects): This factor was loaded by three phrases, and this factor was interpreted as $(19.005 \%)$ of the total variance of terms.

- The third factor (applying storage systems and control method): This factor was loaded by two phrases, and this factor was interpreted as $(18.270 \%)$ of the total variance of terms.

The extracted factors for this axis can be represented according to the Scree Plot test which was created by the scientist Catel 1 as follows:

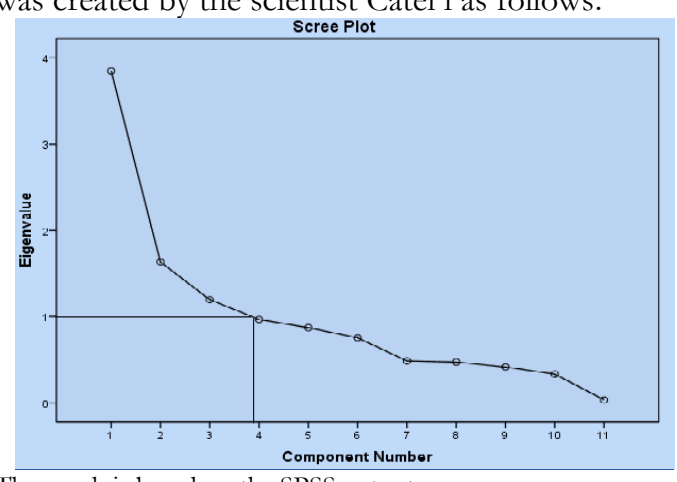

The graph is based on the SPSS output.

Figure (2) graph of Scree Plot Test for the axis of the production processes

From the above we can say that the used scales in this research regarding the axis or section related to the variables of the axis of the production processes all have the credibility of the Convergence Validity for the following reasons:

1- The conditions for using the main factor analysis are achieved:

- The absolute value of the parameter of the correlation coefficients matrix is not equal to zero, the value of the parameter here is Determinant $=$ 0.005 .

- The Kaiser-Meyer-Olkin (KMO) scale is 0.746 and is larger than the desired limit (0.70). This indicates that the size of the sample is well enough. The unacceptable limit is less than 0.50.

- The Bartlett test is 0.000 , which is less than 0.05 , (0.05 is the level of significance in statistical analysis or probability of error, whereas most statistical analyzes are performed at a confidence level of $95 \%$ ), therefore the significant correlation between some variables are enough to use the method of 
factor analysis, and table (14) shows the results of the $\mathrm{KMO}$ and Bartlett test.

Table (14) results of the KMO and Bartlett testing for the production processes

\begin{tabular}{|c|c|c|}
\hline KMO TEST & \multicolumn{2}{|c|}{0.746} \\
\hline \multirow{3}{*}{ Bartlett TEST } & Approx. Chi-Square & 553.155 \\
\cline { 2 - 3 } & Degrees of freedom & 55 \\
\cline { 2 - 3 } & significance & 0.000 \\
\hline
\end{tabular}

The table was prepared based on the results of the statistical analysis of the questionnaire.

2- The saturations of the scale phrases on the extracted factors are strong and greater than the appropriate acceptance limit (0.55) for a sample size between (100) form and (120) form. The Eigen values before the rotation for the extracted factors are greater than one and are achieving the Eigen value criterion.

3- The percentage of interpreted variance of the extracted factors is $(60.665 \%)$, which is higher than the accepted minimum in social research $(60 \%)$.

\section{1-Results and Discussion:}

The researcher tested the hypothesis of the research statistically using SPSS 19. The Regression Test was carried out in order to determine the significance of the regression models and calculate the regression parameters for all the studied variables, and then preparing the regression equations. We are adopted on F-Test, T-Test to determine the significance of the resulting regression equations and the significance of the variables.

To determine whether there is a significant impact of the quality control on the quality of production processes, the researcher performed a regression analysis and the results were as follows:

Table (15) significance of the regression model of the axis of the production processes

\begin{tabular}{|c|c|c|c|c|c|c|}
\hline Mode 1 & $\begin{array}{c}\text { Sum of } \\
\text { Squares }\end{array}$ & df & $\begin{array}{c}\text { Mean } \\
\text { Square }\end{array}$ & F & Sig. & $\begin{array}{c}\text { Statistical } \\
\text { significanc } \\
\text { e }\end{array}$ \\
\hline Regression & 4.646 & 1 & 4.646 & 26.378 & 0.000 & significant \\
\hline Residual & 19.020 & 108 & 0.176 & & & \\
\hline Total & 23.666 & 109 & & & & \\
\hline
\end{tabular}

Table (15) shows that the model of the axis of production processes is significant, where the value of sig is $(0,000)$ which is smaller than 0.05 , this indicates there is a statistically significant impact of the quality control on the production processes. Table (16) shows the significance of the regression model of the production processes.

Table (16) the parameters of the regression model of the axis of the production processes

Coefficients

\begin{tabular}{|c|c|c|c|c|c|c|}
\hline \multirow{2}{*}{ Model } & \multicolumn{2}{|c|}{$\begin{array}{c}\text { Unstandardized } \\
\text { Coefficients }\end{array}$} & \multirow{2}{*}{$\begin{array}{c}\begin{array}{c}\text { Standardized } \\
\text { Coefficients }\end{array} \\
\text { Beta }\end{array}$} & \multirow{2}{*}{$\mathrm{t}$} & \multirow{2}{*}{ Sig. } & \multirow{2}{*}{$\begin{array}{c}\text { Statistical } \\
\text { significance }\end{array}$} \\
\hline & B & $\begin{array}{l}\text { Std. } \\
\text { Error }\end{array}$ & & & & \\
\hline Constant & 2.790 & 0.240 & & 11.64 & 0.000 & significant \\
\hline $\begin{array}{c}\text { Independent } \\
\text { variable }\end{array}$ & 0.325 & 0.063 & 0.443 & 5.136 & 0.000 & significant \\
\hline
\end{tabular}

Dependent variable
The table was prepared based on the results of the statistical analysis of the questionnaire.

Table (16) shows that the value of Sig is $(0,000)$ which is less than 0.05, this indicates there is a statistically significant impact of the quality control on the production processes at a level of $5 \%$.

Thus the null hypothesis, that there is no statistically significant impact of the quality control on the production processes, is rejected in favor of accepting the alternative hypothesis:

There is a statistically significant impact of the quality control on the production processes.

From the above, the equation of regression model for the axis of production processes takes the following form:

$\mathrm{Y}=\mathrm{b} 0+\mathrm{b} 1 \mathrm{X}$

$\mathrm{Y}=2.790+0.325 \mathrm{X}$

$\mathrm{Y}$ : The dependent variable in the regression equation which represents the production processes.

$\mathrm{X}$ : Independent variable (the quality control) which affects the variable $Y$..

\section{2- Conclusions:}

Through using the statistical method in the company shows that production processes within the limits of quality control, where the research relied on conducting a questionnaire to determine the extent of the workers' knowledge of the concept of quality control. Consequently, it has been concluded that applying the quality control in the company leads to improve the quality of production processes, which in turn will positively affect the quality, design and performance of the finished product, where the defects in the product will decrease and therefore the waste and production costs will decrease, to get a product with good specifications and less cost to achieve a competitive advantage in the market.

The researcher proposes to adopt the principle of quality control in the company (or any other company) more effectively to improve the reality of production processes and take advantage of technological development in the field of control to improve the quality of product.

The researcher recommended the need to form an administrative structure or forming a team work to improve the quality or using the consultants and researchers in order to supervise on the principle of quality control.

\section{3- References:}

[1] Elihar Fella, "The Role of Quality in Achieving the Competitive Advantage of the Organization", Master Note, Faculty of Economics and Management Sciences, Blida 2004-2005, P5.

[2] Mohamed Ismail Omar, "Basics of Quality in Production", Dar Al Kutub Al Arabi for Publishing, Cairo, Egypt, 2000, P30.

[3]Fahima Badisi, "Total Quality Management between Theory and Practice", Montessori University, Journal of Humanities, No. 21, Algeria, 2004, P15. 
[4] Carol, A. Reeves and David. A. Bedner, "Defining Quality Alternatives Implications, Academy of Management Review", Vol (19), 1994, P419-420.

[5] Raad Abdullah Al-Taai and Issa Kadada, "Total Quality Management", ed1, Dar Al Yazouri Scientific Publishing and Distribution, Amman / Jordan, 2008, P29.

[6] Nassira Bouzid, "Total Quality Management in the University", Master Thesis, University of Tlemcen, Algeria 2010-2011, P15.

[7] Bilal Megouri, "The Role of Control in Improving Product Quality", University of Ouargla, Algeria 2011-2012, P52.

[8]Moayad Akram Arslan, "The Effect of Implementing the ISO 9001-TQM System on Competitive Policy", $\mathrm{PhD}$ at St.Clements International University, 2012, P58-59.

[9] Adil Hassan, "Problems of Industrial Production", University Youth Foundation, Alexandria, Egypt 1998, P36.

[10] Omar Al-Sa'eed and others., "Principles of Modern Management", 1st ed., Dar Al Thaqafa Library for Publishing and Distribution, Amman 2003, P133.

[11] Ali Al-Sharif, "Administration and Modernity", Alexandria University House, Egypt 20022003, P365.

[12] Tarek Al-Khir, "Using the Quality Control Maps in Industrial Public Sector Companies in Syria", Damascus University Journal Volume 17, No 2, 2001.

[13] J.M Juran , editor "quality control " hand book MC Graw-Hill, 3 edition, Newyourk,1974.

[14] Amal Kaheila, "The Use of Statistical Tools in Product Quality Control", University of Skikda, Algeria 2006-2007, P57.

[15] Mamoun Suleiman Daradka, "Total Quality Management and Customer Service", ed 1, Dar Safa for Publishing and Distribution/Amman, Jordan, 2006, P103.
[16] Ameen Ali Zahra," Developing Design and Production Processes By Using Total Quality Management", Al-Baath University, Syria 2015, P13.

[17] Mahmoud Fahad Abdul Ali, "Production and Operations Management", College of Business and Economics, University of Baghdad, 20162017, P19.

[18] Aida Nakhla Rizkullah, "A Guide for Researchers in Statistical Analysis, Selection and Interpretation", Al-Bayan for Printing, Ain Shams University, 2002, P339.

[19] Hair, J.F, et al, "Multivariate Data Analysis", 5th Ed, Prentice - Hall International, INC, New York, 1998, P115.

[20] Hair F, et al, "Multivariate Data Analysis", 5th Ed, Prentice - Hall International, INC, New York, 1998, P117.

[21] Ahmed Al-Rifai Ghunaim, "Methods of Statistical Analysis", Dar Qbaa for Printing and Publishing, Cairo, 2000, P197.

[22] Aida Nakhla Rizkullah, "A Guide for Researchers in Statistical Analysis, Selection and Interpretation", Al-Bayan for Printing, Ain Shams University, 2002, P341.

[23] Hair, J.F, et al, "Multivariate Data Analysis", 5th Ed, Prentice - Hall International", INC, New York, 1998, P134.

[24] Aida Nakhla Rizkullah, "A Guide for Researchers in Statistical Analysis, Selection and Interpretation", Al-Bayan for Printing", Ain Shams University, 2002, P348.

[25] Leech, L N et al, "SPSS for Intermediate Statistics: Use and Interpretation", 2nd ED, Lawrence Erlbaum associates inc, New jersey, 2005, P245.

[26] Aida Nakhla Rizkullah," A Guide for Researchers in Statistical Analysis, Selection and Interpretation", Al-Bayan for Printing, Ain Shams University, 2002, P348. 